\begin{tabular}{|c|c|c|c|c|c|c|}
\hline \multirow{4}{*}{ Impact Factor: } & ISRA (India) & $=3.117$ & SIS (USA) & $=0.912$ & ICV (Poland) & $=6.630$ \\
\hline & ISI (Dubai, UAE & $=0.829$ & РИНЦ (Russia) & $=0.156$ & PIF (India) & $=1.940$ \\
\hline & GIF (Australia) & $=0.564$ & ESJI (KZ) & $=8.716$ & IBI (India) & $=4.260$ \\
\hline & JIF & $=1.500$ & SJIF (Morocco) & $=5.667$ & OAJI (USA) & $=0.350$ \\
\hline
\end{tabular}

\section{SOI: $\underline{1.1 / T A S}$ DOI: $\underline{10.15863 / \mathrm{TAS}}$ \\ International Scientific Journal Theoretical \& Applied Science}

p-ISSN: 2308-4944 (print) e-ISSN: 2409-0085 (online)

Year: $2019 \quad$ Issue: $06 \quad$ Volume: 74

Published: $19.06 .2019 \quad \underline{\text { http://T-Science.org }}$

SECTION 13. Geography. History. Oceanology. Meteorology.
QR - Issue

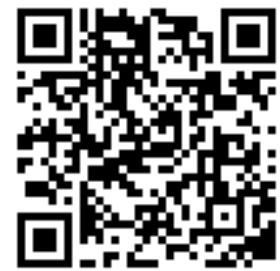

\title{
PLANTS GROWING IN THE TERRITORY OF ANDIJAN REGION AND PROBLEMS OF PROTECTING THEM
}

Muminjon Mamajonov

Andijan State University

Professor of Department of Geography

Abstract: This article discusses the varieties of plants found in the Andijan region, their geographical distribution, their habitat and their use, and the ecologic protection of the environment. The natural and anthropogenic factors affecting the habitat of wild-growing plants in Andijan region are elucidated.

Key words: Nature zones, relief, climate, precipitation, valley, oasis, hill, mountain, air temperature, Central Asia, type, species, family, region.

Language: English

Citation: Mamajonov, M. (2019). Plants growing in the territory of Andijan region and problems of protecting them. ISJ Theoretical \& Applied Science, 06 (74), 325-327.

Soi: http://s-o-i.org/1.1/TAS-06-74-41 Doi: crossef https://dx.doi.org/10.15863/TAS.2019.06.74.41

\section{INTRODUCTION}

The geographical location of our country, the size of its territory, especially the distance from the west to the east, extension of about $1400 \mathrm{~km}$, the existence of several natural zones between these distances, the diversity of the land of Uzbekistan in the formation of such zones, the differentiation of climatic zones and the increase of precipitation from the plains to the mountains cause flora to be colorful.

\section{MAIN PART}

Depending on natural and geographical conditions, vegetation varieties will grow richly from the steppe to its valleys and oases, to the hills and mountains. Despite the disadvantages of natural conditions in most of the country's territory, high temperatures in summer, sunny days, low levels of precipitation, about 4500 species of high-yielding plants grow from 166 families, despite the limitations of their flora. The overwhelming majority of these plants, or about 260 species, are representatives of large families, such as families of willow-herb, orach, tulips, clove pink, carnivores, hybrids, Austrian brier.

The appearance of our country's flora, distribution, types, species and general similarity of their families are like the flora of neighboring countries in Central Asia. The flora of Uzbekistan is studied pursuant to areas of steppe, hills, mountains, and meadows in accordance with the laws set by the academician of Uzbekistan Science Academy K.Z.Zokirov.

Based on these laws, the flora of Andijan region also varies from Ulughnor and Boz districts, regarded as steppe zone, to the east. There are plains, lowmountainous vegetation in the region and are divided into the following: 1. Black Saxaul - white saxaul deserts that are mainly spread in the western part of Ulughnor district - in Mingchinor village and the fish farms and they do not cover a large area. This plant is a plant that grows in the sandy steppe and white saxaul grows between 4 to 5 meters in height on sandy dunes, and black saxauls grow in holes among sandy dunes. In the areas where white saksaul grows, treelike saltwort, chogon, locoweed, and various bushlike plants grow.

There are also tugai and reed tangles in the region, where there are turuncules, pussy willow oleaster, tamarisk, salt cedar, clematis, trailing bindweed coiling trees and bushes, such as orach, bur, as well as sea buckthorn.

Foothill and mountain plants (these plants include semi-stepe plants ephemer - ephemeroid). These plants are found in Otchopar area of Andijan district, in foothill areas of Asaka and Marhamat districts and foothill areas of Honobod.

The ephemer and ephemeroid plants, such as sedge, brownhead plant, violet, snowdrop, poppy, ixioliorione, dandelion grow densely in lush in spring 


\begin{tabular}{|c|c|c|c|c|c|c|}
\hline \multirow{4}{*}{ Impact Factor: } & ISRA (India) & $=3.117$ & SIS (USA) & $=0.912$ & ICV (Poland) & $=6.630$ \\
\hline & ISI (Dubai, UAI & $=0.829$ & РИНЦ (Russia & $=0.156$ & PIF (India) & $=1.940$ \\
\hline & GIF (Australia) & $=0.564$ & ESJI (KZ) & $=8.716$ & IBI (India) & $=4.260$ \\
\hline & JIF & $=1.500$ & SJIF (Morocce & $=5.667$ & OAJI (USA) & $=0.350$ \\
\hline
\end{tabular}

in sandy areas of Ulugnor, which is called sandy territory of the region.

Hilly highlands region cover the areas of 400500 to 1350 meters in hilly areas of Honobod, Sultonobod of Kurgantepa district, Southern Olamushuk, Oyim, Teshiktosh of Jalakuduk district, Manak, Karnaychi of Hojaobod district, Shirmonbulok of Bulokboshi district, southern parts and Polvontosh hilly areas, Asaka hilly areas of Asaka ditrict, 1545 meters in the south of Hojaobod. As the relief rises in these places, the amount of precipitation increases, typical virgin soil is widespread as summer temperature is lower than those of flat country and low desert zones. This feature of the climate is the result of intense and high growth of various herbs in these areas. The bottom of the hill, consisting of depth and dunes, is broken down by the temporary running waters caused by precipitation, while the sides in upper part are steep and mother genital organs are opened. Consequently, the vegetation cover on the hillsides is not covered up well and grows with occasional breaks, because in places where the water is washed out, the mother genital organs are opened and the oreal leaves of the vegetation cover are cut off.

In the hilly region, there are more plant species in the desert than those in steppe and they grow in lush. In some areas, there are about 15-20 species in the 1 square kilometer area. The basis of the herbaceous plants consist of ephemeral and ephemeroid plants, herbage and bushes of many years. Ephemeroid plants, such as brownhead plant, brome of danthonia, chick-pea, ixioliorione, poppy, snowdrop, hollyhock, dandelion grow densely on the hills and keep on their vegetation until June. Besides these plants, mugwort, wild wheat, wild barley, jasmine, bindweed, coral bean, madderwort, common plantain, soapwort grow and treelike plants are found on the upper part of hills.

The highest point of Andijan region is Kirtoshtov mountain located in in the south of Hojaobod district. Its highest point is 1545 meters, the height of Qoratag in Honobod is 1350 meters, besides, although Karnaychi, Manak, Dilkushod of Hojaobod district, Shirmonbuloq in Bulokboshi district, Kora (Black) hill in Marhanat district, Asaka hills and mountains located between Asaka and Marhamat are not so high, there are plants of foothills and mountainous region related to mountains. Although the relief is not so complicated in these highlands, there are hollows and ravines among the range of mountains, the plants in this place are entirely different from those in flat countries and hilly areas. There is a significant difference between the northern part and southern part of the mountains; first of all it is noticeable in different amount of dampness, depending on which there is a difference in the number of plant species, their density and sparseness.

Climatic features also change depending on the relief. The amount of precipitations gradually increases in mountainous regions, the temperature is lower in summer, precipitations fall especially on northern, northern-western sides of the mountains, as a result the soil changes too. Brown soil is found on arid side of the mountains and dark virgin lands and typical virgin soil are found on the side where there is more dampness.

There are mesophytic plants in damp sides northern and northern-western part of the mountains and on the contrary, there are xerophytic plants in arid sides - southern part of the mountains. Moreover, completely ripe weeds and sagebrush semi-desert plants, trees and bushes with broad leaves grow in foothills and low mountains.

River vallies and estuaries plants, mainly, correspond to developed and cultivated landscapes of the region. Almost cultivated plants grow in these places.

Plant resources and their protection are among the most important tasks since all resources are of practical importance in the development of nature and society, but the vegetative world is not only a natural resource, but also a major tool for maintaining the balance of nature. Regardless of the type of famil or species of plant, it is also important in nature, in the process of carrying out gas, energy exchange, as food, construction material, and as material of medication. Although plants are a good source of moisture, regulating the flow of rivers, preventing soil erosion, strengthening the sand and keeping the air clean, it is also important for people to relax and enjoy the aesthetic pleasure.

Plant resources serve as an important source of nutrition for livestock development, as a pasture for sheep breeding, a major source of hay and forage production.

The plant world is a source of life for the bees, which hold an important place in regenerating human health, preparing medications for its improvement, and play an important role in the development of nature. While collecting nectars from plant flowers, bee pollinates, fertilizes them and serves to cause new species.

Wild plants growing in the region, mainly, as the academician K.Z.Zokirov emphasized, are spread in accordance with highland regions of flat countries, hills, mountains and meadows. This case is characterized with that plants, which have the features of flat countries, hilly, mountainous (low mountains) regions for Andijan region.

Several representatives of plants that grow in Uzbekistan are peculiar to Andijan and they are the followings: sophora, wild grass, hollyhock, common plantain, dog-rose, blackberry bush, timothy, licorice, sagebrush, common wormwood, bur, horsetail, orach, reed, datura and other plants. These plants have many features and are widely used in the treatment of various diseases. In our region there are beautiful flowering plants - tulip, poppy, snowdrop, ixiliorione, 


\begin{tabular}{|c|c|c|c|c|c|c|}
\hline \multirow{4}{*}{ Impact Factor: } & ISRA (India) & $=3.117$ & SIS (USA) & $=0.912$ & ICV (Poland) & $=6.630$ \\
\hline & ISI (Dubai, UAI & $=0.829$ & РИНЦ (Russia & $=0.156$ & PIF (India) & $=1.940$ \\
\hline & GIF (Australia) & $=0.564$ & ESJI (KZ) & $=8.716$ & IBI (India) & $=4.260$ \\
\hline & JIF & $=1.500$ & SJIF (Morocce & $=5.667$ & OAJI (USA) & $=0.350$ \\
\hline
\end{tabular}

dandelion, which give aesthetic pleasure to people's mood in early spring, which are spread in deserts, steppes, hills, foothills, mountains and valleys. They cover the nature in March, April, and May, giving them a beauty.

Today, as in all regions of our country, Andijan region is undergoing major changes and improvements. This development is especially noticeable in the use of nature, especially in the use of land resources, which is evident in the use of soil resources. The sands of Ulugnor district, as well as the soils of the adjacent areas of the region, as a construction material, have changed the natural landscape and cause the plant species to disappear. This leads to the decline and degradation and extinction of wild-growing plant species in the region, resulting in the poorest vegetation. In the process of irrigation works through pumps, the process of land washing and loosening is increasing as a result of the installation of gardens on the terrace for the purpose of development of horticulture and viticulture in the hilly area and changes in landscapes cause many plant species to decline, and their oreales are cut off and the plant species disappear.

\section{CONCLUSION}

As the challenge of preserving and increasing the naturally-occurring plant varieties in Andijan, as well as the task of the whole world community, is one of the most important issues to preserve and increase the nature of the present day as a whole of the world community, in order to accomplish this task, we must adhere to:

1. Educate the younger generation with kindness and love for the nature, conduct educational activities on nature-related educative issues in preschool children, give them insight into the uniqueness of nature and its components.

2. In natural science, geography lessons in general education schools, the students should be taught the nature, the love of the motherland, and achieve the ecological knowledge through deep scientific and practical training on natural resources and their importance.

3. Providing students with specialization in higher education, providing knowledge and skills on maintaining unique nature on the basis of local history.

4. In reaching out to the economic interests of the population, it is important for them to take measures to prevent damage to nature (water, soil, vegetation and animal world).

5. The proper preservation of the natural world of the Republic of Uzbekistan, in particular the vegetation world of Andijan region, is one of the most important tasks of today: to stop the illicit attitude towards the flora.

The plant is a unique creature not only for human life, but also for the whole of the world, and it needs to be remembered and constantly treated correctly.

\section{References:}

1. Karimov, I. A. (1997). Uzbekistan at the turn of the twenty-first century: security threats, stability and guarantees of progress. Tashkent: Uzbekistan.

2. Madumarov, T., Mamajonov, M., Mamatyusupov, A. S., \& Isayev, A. (2015). Andijan region atlas of countrylearning. Tashkent.

3. (1982). Atlas of Uzbek Republic, Part one. Moscow-Tashkent.

4. (2010). Atlas of the soil cover of the Republic of Uzbekistan. Tashkent.

5. Abdulkasimov, A. A. (1963). Physicalgeographical areas of the Fergana Hollown.
Science. Voronezh. Department of Geographical Society. USSR. Voronezh.

6. Abdulkasymov, A. A. (1964). Landscapetypological mapping and physiographic zoning of the Fergana Hollow: Abstract of Candidate of Geological Science. Voronezh.

7. Babushkin, L. N., Kogai, N. A., \& Zokirov, S. S. (1975). Acroclimatic conditions of agriculture of Uzbekistan. Tashkent: Mehnat.

8. Babushkin, L. N. (1954). Physical-geographical areas. Fergana Valley. Tashkent.

9. Baratov, P. (1996). The natural geography of Uzbekistan. Tashkent: Ukituvchi.

10. Bogdanov, O. P. (1996). Animals of Uzbekistan. Tashkent: Ukituvchi. 